\title{
Masseundersøkelser mot gynekologisk kreft - status og fremtid $Q$
}

\begin{abstract}
Sammendrag
Bakgrunn. Masseundersøkelse mot livmorhalskreft ble innført i Norge i 1995. Målsettingen var å redusere insidens og mortalitet med rasjonell bruk av ressurser. Tiltaket har hatt god effekt. Vi ønsket å gjennomgå kunnskapsgrunnlaget for masseundersøkelse mot livmorhalskreft og å vurdere om det finnes dokumentasjon for nytte av masseundersøkelser mot eggstokkreft og livmorlegemekreft.
\end{abstract}

Materiale og metode. Grunnlaget for artikkelen er et ikke-systematisk litteratursøk i PubMed med et skjønnsmessig utvalg av artikler basert på forfatternes erfaring innen feltet.

Resultater. Det er så langt ikke kunnskapsgrunnlag for å innføre masseundersøkelser mot livmorlegemekreft, selv om flere risikofaktorer er kjent. I løpet av noen år avklares det om store pågående studier viser tilstrekkelig god effekt til at masseundersøkelse mot eggstokkreft kan anbefales. Effekten av masseundersøkelse mot livmorhalskreft er godt dokumentert.

Konklusjon. Livmorhalskreft er den eneste gynekologiske tilstanden med et etablert masseundersøkelsesprogram. Dette programmet må tilpasses nye metoder og befolkningens vaksinestatus i årene som kommer. Masseundersøkelse mot eggstokkreft mangler kunnskapsgrunnlag, men dette kan endres i løpet av få år.

\section{Trond Melbye Michelsen}

trond.melbye.michelsen@rikshospitalet.no Kvinne-og barneklinikken

Oslo universitetssykehus, Rikshospitalet og

Forskningsenheten

Sørlandet sykehus

\section{Ole-Erik Iversen}

Kvinneklinikken

Haukeland universitetssykehus

og

Institutt for klinisk medisin

Universitetet i Bergen

Masseundersøkelser mot kreft tar sikte på å oppdage kreftsykdom på et tidlig stadium for å bedre utfallet av sykdommen. En effektiv masseundersøkelse krever at sykdommen opptrer med en viss hyppighet, at det naturlige forløpet er kjent, at det finnes effektiv behandling mot sykdommen, at sykdommen er en betydelig dødsårsak og at undersøkelsesprosedyren er akseptabel for pasientene (1). I denne artikkelen ser vi på masseundersøkelser mot de tre vanligste formene for gynekologisk kreft: livmorlegemekreft (corpuscancer), eggstokkreft (ovarialcancer) og livmorhalskreft (cervixcancer). Andre former for gynekologisk kreft forekommer så sjelden at det ikke er naturlig å vurdere masseundersøkelser.

\section{Materiale og metode}

Artikkelen er basert på ikke-systematisk søk i PubMed og på forfatternes erfaring innen fagfeltet.

\section{Livmorlegemekreft}

I 2008 ble det registrert 716 nye tilfeller av livmorlegemekreft i Norge, og sykdommen er dermed den hyppigste gynekologiske kreftformen (2). I perioden 2004-08 var den relative femårsoverlevelsen uansett stadium $83 \%$ og for lokalisert sykdom over $90 \%$ (2). Livmorlegemekreft oppdages oftest i tidlig stadium, og tidlig behandling gir bedret overlevelse. Derfor er antallet dødsfall knyttet til livmorlegemekreft lavt, og sykdommen er ikke en betydelig dødsårsak i Norge.

Det finnes så langt ikke noen ideell metode for masseundersøkelse mot livmorlegemekreft. Vaginal ultralyd har usikker grense for endometrietykkelse og lav spesifisitet. Endometriebiopsi og endometriecytologi har høy sensitivitet, men lav positiv prediktiv verdi. I tillegg er metodene invasive og derfor lite egnet for masseundersøkelse. Det er enighet både nasjonalt $\mathrm{og}$ internasjonalt $\mathrm{om}$ at $\mathrm{det}$ ikke er grunnlag for masseundersøkelser mot livmorlegemekreft $(3,4)$.

Kvinner med hereditær ikke-polypøs coloncancer har livstidsrisiko for livmorlegemekreft på 20-50\%. Disse kvinnene tilbys i dag årlig vaginal ultralyd og eventuelt endometriebiopsi fra 35 års alder (5).

\section{Fremtidsperspektiver}

Fordi man ikke har gode nok metoder og fordi sykdommen ikke er en betydelig dødsårsak, er det ikke aktuelt å innføre masseundersøkelser mot livmorlegemekreft.

\section{Eggstokkreft}

Om lag 450 norske kvinner får eggstokkreft hvert år. Femårsoverlevelsen for alle stadier er så lav som $44 \%$, og i 2007 døde 315 kvinner av eggstokkreft i Norge. Eggstokkreft er derfor en betydelig dødsårsak. Så mange som $70 \%$ har avansert sykdom ved diagnosetidspunktet. Sannsynligvis kunne overlevelsen vært bedret dersom man kunne påvise flere tilfeller på et tidlig stadium. Problemet er at sykdommens naturlige forløp ikke fullt ut er kjent. I tillegg mangler man en fullgod metode for å avdekke sykdommen i tidlig stadium.

Undersøkelser der man har benyttet vaginal ultralyd for å finne eggstokkreft i tidlig stadium viser sprikende resultater, med positiv prediktiv verdi på $1-27 \%$. Det er enighet om at en masseundersøkelse mot eggstokkreft bør ha positiv prediktiv verdi på minst $10 \%$. Resultatene ser ut til å variere betydelig avhengig av utvalg og undersøker. I flere studier har man konkludert med at masseundersøkelse mot eggstokkreft med vaginal ultralyd ikke har effekt, fordi mange krefttilfeller påvises mellom to ultralydundersøkelser og fordi majoriteten av kreft-

\section{Hovedbudskap}

- Det er ikke vitenskapelig grunnlag for masseundersøkelse mot livmorlegemekreft

- Masseundersøkelse mot eggstokkreft er ikke aktuelt før pågående studier viser eventuelle positive resultater

- Masseundersøkelsen mot livmorhalskreft må fortsette, også etter innføring av vaksine 
tilfellene er i avansert stadium også i masseundersøkelsesgruppene $(6,7)$. Cancerantigen 125 (CA-125) er en serummarkør som er forhøyet hos $80 \%$ av pasientene med avansert eggstokkreft og hos 1-2\% i den generelle befolkningen (8). CA-125 er imidlertid bare forhøyet hos $50 \%$ med eggstokkreft i tidlig stadium (9), og den er derfor ikke egnet til bruk alene som masseundersøkelsesmetode. Ved gjentatte målinger hos samme individer er det vist at CA-125 stiger fra basalnivået $i$ tiden før eggstokkreftdiagnosen (10). Det er derfor utviklet en algoritme som beregner risiko for eggstokkreft basert på gjentatte CA-125-målinger (11).

I en britisk randomisert klinisk studie fikk 10000 kvinner tre årlige screeninger med CA-125, De ble henvist til vaginal ultralyd ved verdier over $30 \mathrm{mU} / \mathrm{l}$. Sammenliknet med kontrollgruppen uten intervensjon $(\mathrm{N}=10000)$ hadde de screenede kvinnene signifikant bedre spesifikk eggstokkreftoverlevelse (12).

Det pågår for tiden to store, randomiserte kliniske studier der man evaluerer måling av CA-125 sammen med vaginal ultralyd for å diagnostisere eggstokkreft. I den amerikanske multisenterstudien Prostate, Lung, Colorectal and Ovarian Cancer Screening Trial (PLCO) i regi av National Cancer Institute (NCI) har man randomisert 34000 kvinner i alderen 55-74 år til årlig vaginal ultralyd og måling av CA-125 (etterfulgt av to år med CA-125-måling) eller standard oppfølging.
Inklusjonen pågikk i perioden 1993-2001, og kvinnene skal følges i 13 år. I 2009 ble resultatene fra de første fire årene etter randomisering publisert. Av totalt 89 tilfeller av eggstokk- eller bukhinnekreft i intervensjonsgruppen ble 60 oppdaget ved screening, mens 29 tilfeller ble oversett. Det ble ikke presentert sammenliknbare data fra kontrollgruppen. Forfatterne anga at man måtte operere 20 pasienter for hvert tilfelle av kreft (13). The United Kingdom Collaborative Trial of Ovarian Cancer Screening (UKCTOCS) er en britisk multisenterstudie der 202000 kvinner i alderen 50-74 år er randomisert 2:1:1 til ingen masseunders $\varnothing$ kelse, årlig måling av CA-125 med algoritme for eggstokkreftrisiko og vaginal ultralyd som oppfølgingsundersøkelse (multimodal gruppe) eller årlig vaginal ultralyd alene. Inklusjonen pågår ut 2011 og kvinnene skal følges ut 2014 med dødelighet som endepunkt. Resultater fra første masseundersøkelsesrunde viser at 28 av 58 tilfeller av eggstokkreft oppdaget i multimodal gruppe var i stadium I eller II. Positiv prediktiv verdi i den multimodale gruppen var $35 \%$, mot $3 \%$ i vaginal ultralyd-gruppen (14). PLCO-resultatene er nedslående, mens de første resultatene fra UKCTOCS er positive. Det trengs data på mortalitet i de ulike gruppene, og det vil det ta minst tre år å få. Det er derfor ikke grunnlag for å innføre masseundersøkelse mot eggstokkreft på det nåværende tidspunkt.

\section{Fremtidsperspektiver}

Per i dag er det ikke dokumentert nytte ved å innføre masseundersøkelser mot eggstokkreft. I løpet av noen år ventes avklaringer fra store pågående studier.

\section{Livmorhalskreft}

Infeksjon med humant papillomvirus (HPV) er en direkte, men ikke alene tilstrekkelig årsak til livmorhalskreft. Opptil $70 \%$ av seksuelt aktive vil bli smittet av en HPVinfeksjon én eller flere ganger i løpet av livet $(15,16)$, og $2-20 \%$ av seksuelt aktive kvinner er infisert til enhver tid (17). I Norge er det vist at $25 \%$ av kvinner under 25 år er eller har vært smittet med viruset (18). Genitale HPV-infeksjoner bekjempes hos 70-90\% i løpet av 12-18 måneder (19). Særlig er dette utpreget hos unge kvinner (20-22) (fig 1). Persisterende infeksjon med høyrisiko-HPV gir økt risiko for livmorhalskreft (23). Utviklingen fra HPVinfeksjon til invasiv kreft går via detekterbare forstadier med cervikal intraepitelial neoplasi (CIN). Kjennskapen til disse forstadiene er grunnlaget for masseundersøkelsen mot livmorhalskreft, som har bidratt både til en reduksjon av insidens og mortalitet av livmorhalskreft (24). Status i Norge per 2008 er en mortalitetsreduksjon på $50 \%$ og en insidensreduksjon på $30 \%$ sammenliknet med året før oppstart av masseundersøkelsen (1994) (25).

Cytologisk undersøkelse av livmorhals-

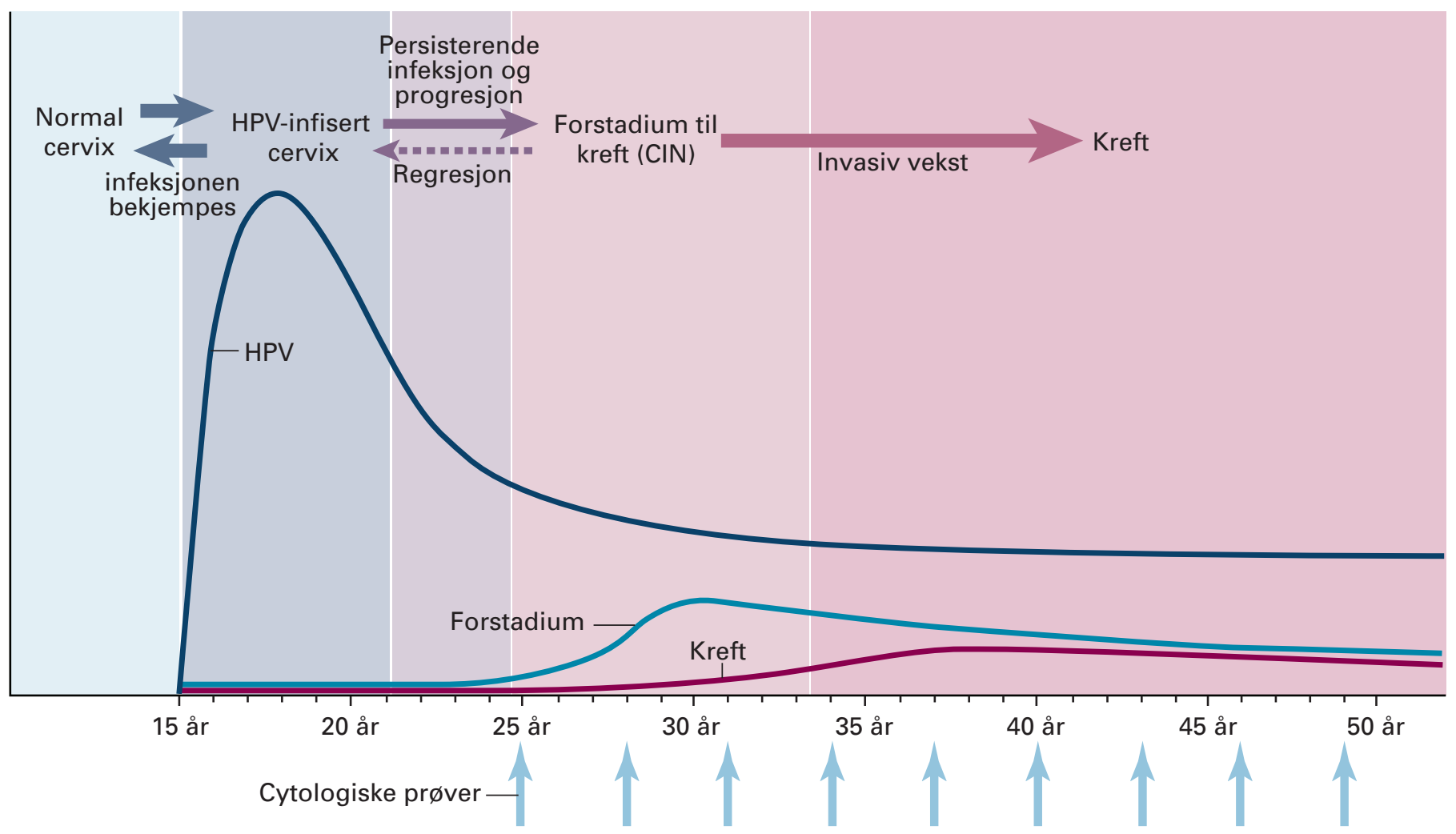

Figur 1 Naturlig forløp av HPV-infeksjon og utvikling av forstadier til livmorhalskreft. Kvinner i tenårene og i tjueårene har høyest forekomst av HPV-infeksjon. De fleste bekjemper infeksjonen. Noen av de som får bestående infeksjon med høyrisiko-HPV utvikler forstadier til livmorhalskreft etter $10-15$ år. Figuren er omarbeidet fra Schiffman \& Castle (22), med tillatelse 
slimhinnen ble først beskrevet av Papanicolaou for snart 70 år siden (26). Cytologisk undersøkelse, både konvensjonell og væskebasert, har lav sensitivitet og høy spesifisitet for påvisning av livmorhalskreft $(26,27)$. Cytologisvar kategoriseres nå etter Bethesdakriteriene (28). For kvinner med histologisk bekreftet grove celleforandringer (CIN 2+ eller adenocarcinoma in situ), mistanke om mikroinvasjon eller uavklart histologisk diagnose anbefales konisering. Det gjøres om lag 3000 koniseringer i Norge per år. Konisering gir økt risiko for fødsel før termin (29). I Sverige ble det i en stor, populasjonsbasert registerstudie vist økt risiko for kreft i livmorhals og vagina hos kvinner behandlet for CIN 3 (30).

Det er identifisert over 200 ulike HPVtyper, men få gir høy risiko for kreft. HPV16 og HPV-18 knyttes til om lag $70 \%$ av tilfellene av livmorhalskreft, og $90 \%$ av krefttilfellene forårsakes av åtte ulike HPVtyper $(31,32)$. Det finnes flere ulike HPVtester på markedet. Som ledd i et prøveprosjekt brukes HPV-test i Norge som sekundærscreening (triage) av celleprøver med atypiske plateepitelceller av usikker signifikans (ASCUS) og lavgradig plateepitellesjon (LSIL). Nytten av triage med HPVtest etter funn av atypiske plateepitelceller av usikker signifikans er godt dokumentert $(33,34)$. Fordi forekomsten av HPV-forandringer er så høy hos unge kvinner (fig 1), vil HPV-test ha lavere prediktive verdier. HPVtest vil derfor fungere best som triage hos kvinner som er over 30-40 år (35).

HPV-test har høyere sensitivitet, men lavere spesifisitet enn cytologisk prøve ved primærscreening $(36,37)$. Brukt som primærscreening hos kvinner over 35 år har HPV-test både høyere sensitivitet og spesifisitet enn celleprøve (38). Fordi HPV-test også har høyere negativ prediktiv verdi, kan man sannsynligvis øke intervallene for undersøkelser ved innføring av HPV-test som primærscreening $(39,40)$.

\section{Vaksine mot livmorhalskreft}

Vaksinene mot livmorhalskreft består av overflateproteiner fra HPV-virus satt sammen til virusliknende partikler. Vaksinene har dokumentert forebyggende effekt på CIN, med over $90 \%$ lavere forekomst av CIN 2 og celleforandringer av høyere grad forårsaket av HPV-16 og HPV-18 når man vaksinerer jenter som ikke har vært eksponert for HPVinfeksjon med disse typene $(41,42)$. Det finnes så langt ikke data som viser reduksjon $\mathrm{i}$ antall krefttilfeller eller redusert dødelighet etter vaksinasjon. HPV-vaksine ble innført i det norske vaksinasjonsprogrammet for jenter i 7. klasse fra skoleåret 2009/2010. Vaksinen gis som tre doser og er i tillegg til HPV16 og HPV-18 virksom mot HPV-6 og HPV11 , som forårsaker ca. $90 \%$ av kjønnsvorter. I det første vaksineåret ble det registrert 190 meldinger om bivirkninger totalt i Norge, hvorav ni alvorlige med sykehusinnleggelser for besvimelse, kramper eller allergi. Ifølge Folkehelseinstituttets nettsider er det ikke rapportert om vedvarende helseplager etter vaksinasjon (43).

Innføring av vaksine mot livmorhalskreft vil senke forekomsten av celleforandringer Positiv prediktiv verdi for celleprøver vil bli lavere med fallende forekomst av celleforandringer. Det bør derfor gjøres nye vurderinger av hvilke tester som er best egnet i masseundersøkelsesprogrammet. Dette blir særlig viktig når de HPV-vaksinerte inngår $\mathrm{i}$ masseundersøkelsen mot livmorhalskreft fra 2023

\section{Fremtidsperspektiver}

Masseundersøkelsen mot livmorhalskreft må fortsette. Selv med full vaksinedekning må man undersøke ikke-vaksinerte kohorter i 50 år fremover. Vaksinen som er innført beskytter ikke mot alle typer høyrisikoHPV, og kan derfor ikke eliminere all livmorhalskreft. Det er beregnet i en britisk studie at med $80 \%$ vaksinedekning vil man kunne redusere forekomsten av livmorhalskreft hos kvinner under 30 år med $2 / 3$ innen 2025 (44). Det er grunn til å tro at innføring av HPV-test som primærscreening, eventuelt med celleprøve som triage, vil bedre resultatene av masseundersøkelsen mot livmorhalskreft.

\section{Konklusjon}

Masseundersøkelsen mot livmorhalskreft fungerer godt, og effekten ser ut til å være god. Undersøkelsesprogrammet må imidlertid tilpasses dagens virkelighet med HPVvaksine og HPV-test. Bortsett fra spesielle undergrupper er det ikke grunnlag for masseundersøkelse mot livmorlegemekreft. Det er heller ikke grunnlag for masseundersøkelse mot eggstokkreft. Nye studier kan imidlertid endre dette.

\section{Trond Michelsen (f. 1976)}

er lege i spesialisering ved Kvinne- og barneklinikken, Oslo universitetssykehus, Rikshospitalet.

Ingen oppgitte interessekonflikter.

\section{Ole-Erik Iversen (f. 1945)}

er spesialist i fødselshjelp og kvinnesykdommer, er overlege ved Kvinneklinikken, Haukeland universitetssykehus og professor ved Institutt for klinisk medisin, Universitetet i Bergen.

Oppgitte interessekonflikter: Han har deltatt i utprøving av HPV-vaksiner produsert av legemiddelselskapene GlaxoSmithKline og Merck, Sharp \& Dohme (MSD) og har mottatt reisestøtte og forelesningshonorar fra MSD.
Litteratur

1. World Health Organization. Screening for cancer www.who.int/cancer/detection/en/ (20.8.2010).

Kreftregisteret Cancer in Norway 2008-2009. www kreftregisteret no (20.8.2010)

3. Smith RA, von Eschenbach AC, Wender R et al. American Cancer Society guidelines for the early detection of cancer: update of early detection guidelines for prostate, colorectal, and endometrial cancers. Also: update 2001-testing for early lung cancer detection. CA Cancer J Clin 2001; 51 $38-75$

4. Salvesen HB. Masseundersøkelse mot endometriekarsinom. Tidsskr Nor Lægeforen 2002; 122 $1774-6$.

5. Norsk gynekologisk forening. Veileder i gynekologisk onkologi 2009. www.legeforeningen.no/id/ 153445.0 (20.8.2010).

6. Hermsen BB, Olivier RI, Verheijen RH et al. No efficacy of annual gynaecological screening in BRCA1/2 mutation carriers; an observational follow-up study. Br J Cancer 2007; 96: 1335-42.

7. Oei AL, Massuger LF, Bulten J et al. Surveillance of women at high risk for hereditary ovarian cancer is inefficient. Br J Cancer 2006; 94: 814-9.

8. Bast RC Jr, Klug TL, St John E et al. A radioimmunoassay using a monoclonal antibody to monitor the course of epithelial ovarian cancer N Engl J Med 1983; 309: 883-7.

9. Woolas RP, Xu FJ, Jacobs IJ et al. Elevation of multiple serum markers in patients with stage I ovarian cancer. J Natl Cancer Inst 1993; 85: 1748-51.

10. Skates SJ, Menon U, MacDonald N et al. Calculation of the risk of ovarian cancer from serial CA-125 values for preclinical detection in postmenopausal women. J Clin Oncol 2003; 21 (suppl): 206-10s.

11. Menon U, Skates SJ, Lewis S et al. Prospective study using the risk of ovarian cancer algorithm to screen for ovarian cancer. J Clin Oncol 2005; 23: $7919-26$

12. Jacobs IJ, Skates SJ, MacDonald N et al. Screening for ovarian cancer: a pilot randomised controlled trial. Lancet 1999; 353: 1207-10.

13. Partridge E, Kreimer AR, Greenlee RT et al. Results from four rounds of ovarian cancer screening in a randomized trial. Obstet Gynecol 2009; 113: 775-82.

14. Menon U Gentry-Maharaj A, Hallett R et al Sensitivity and specificity of multimodal and ultrasound screening for ovarian cancer, and stage distribution of detected cancers: results of the prevalence screen of the UK Collaborative Trial of Ovarian Cancer Screening (UKCTOCS). Lancet Oncol 2009 10: $327-40$

15. Bosch FX, Lorincz A, Muñoz N et al. The causal relation between human papillomavirus and cervical cancer. J Clin Pathol 2002; 55: 244-65.

16. zur Hausen H. Papillomaviruses and cancer: from basic studies to clinical application. Nat Rev Cancer 2002; 2: 342-50

17. Bosch FX, de Sanjosé S. Chapter 1: Human papillomavirus and cervical cancer - burden and assessment of causality. J Natl Cancer Inst Monogr 2003; nr. 31: 3-13

18. Skjeldestad FE, Hagen B, Lie AK et al. Residual and recurrent disease after laser conization for cervical intraepithelial neoplasia. Obstet Gynecol 1997; 90: 428-33.

19. Brown DR, Shew ML, Qadadri B et al. A longitudinal study of genital human papillomavirus infection in a cohort of closely followed adolescent women. J Infect Dis 2005; 191: 182-92.

20. Moscicki AB, Shiboski S, Hills NK et al. Regression of low-grade squamous intra-epithelial lesions in young women. Lancet 2004: 364: 1678-83.

21. Ho GY, Bierman R, Beardsley L et al. Natural his tory of cervicovaginal papillomavirus infection in young women. N Engl J Med 1998; 338: 423-8.

22. Schiffman M, Castle PE. The promise of global cervical-cancer prevention. N Engl J Med 2005; 353: $2101-4$

23. Moscicki AB, Schiffman M, Kjaer S et al. Chapter 5 Updating the natural history of HPV and anogenital cancer. Vaccine 2006; 24 (suppl 3): S3/42-51.

24. Haldorsen T, Skare GB, Steen R et al. Livmorhalskreft etter ti års offentlig koordinert screening. Tidsskr Nor Lægeforen 2008; 128: 682-5.

25. Kreftregisteret. Årsrapport 2008 for Masseundersøkelsen mot livmorhalskreft. www.kreftregisteret.no/no/Generelt/Nyheter/ Arsrapport-fra-Masseundersokelsen-motlivmorhalskreft/ (26.5.2011). 
26. Nanda K, McCrory DC, Myers ER et al. Accuracy of the Papanicolaou test in screening for and followup of cervical cytologic abnormalities: a systematic review. Ann Intern Med 2000; 132: 810-9.

27. Siebers AG, Klinkhamer PJ, Grefte JM et al. Comparison of liquid-based cytology with conventional cytology for detection of cervical cancer precursors: a randomized controlled trial. JAMA 2009 302: $1757-64$.

28. The Bethesda system for reporting cervical cytology. 2 utg. New York, NY: Springer, 2003.

29. Albrechtsen S, Rasmussen S, Thoresen $S$ et al. Pregnancy outcome in women before and after cervical conisation: population based cohort study. BMJ 2008; 337: a1343.

30. Strander B. Andersson-Ellström A, Milsom I et al. Long term risk of invasive cancer after treatment for cervical intraepithelial neoplasia grade 3: population based cohort study. BMJ 2007; 335: 1077.

31. Muñoz N, Bosch FX, Castellsagué X et al. Against which human papillomavirus types shall we vaccinate and screen? The international perspective. Int J Cancer 2004; 111: 278-85.

32. Clifford G, Franceschi S, Diaz M et al. Chapter 3: HPV type-distribution in women with and without cervical neoplastic diseases. Vaccine 2006; 24 (suppl 3): S3/26-34.

33. Arbyn M, Sasieni P, Meijer CJ et al. Chapter 9 . Clinical applications of HPV testing: a summary of meta-analyses. Vaccine 2006; 24 (suppl 3): S3/78-89.
34. ASCUS-LSIL Traige Study (ALTS) Group. Results of a randomized trial on the management of cytology interpretations of atypical squamous cells of undetermined significance. Am J Obstet Gynecol 2003; 188: 1383-92

35. Cotton S, Sharp L, Little J et al. The role of human papillomavirus testing in the management of women with low-grade abnormalities: multicentre randomised controlled trial. BJOG 2010; 117: 645-59.

36. Ronco G, Giorgi-Rossi P, Carozzi F et al. Efficacy of human papillomavirus testing for the detection of invasive cervical cancers and cervical intraepithelial neoplasia: a randomised controlled trial. Lancet Oncol 2010; 11: 249-57.

37. Naucler P, Ryd W, Törnberg S et al. Efficacy of HPV DNA testing with cytology triage and/or repeat HPV DNA testing in primary cervical cancer screening. J Natl Cancer Inst 2009; 101: 88-99.

38. Leinonen M, Nieminen P, Kotaniemi-Talonen $L$ et al. Age-specific evaluation of primary human papillomavirus screening vs conventional cytology in a randomized setting. J Natl Cancer Inst 2009; 101: 1612-23.

39. Dillner J, Rebolj M, Birembaut P et al. Long term predictive values of cytology and human papillomavirus testing in cervical cancer screening: joint European cohort study. BMJ 2008; 337: a1754.

40. Bulkmans NW, Berkhof J, Rozendaal L et al. Human papillomavirus DNA testing for the detection of cervical intraepithelial neoplasia grade 3 and cancer: 5-year follow-up of a randomised controlled implementation trial. Lancet 2007; 370: $1764-72$.

41. FUTURE II Study Group. Quadrivalent vaccine against human papillomavirus to prevent highgrade cervical lesions. N Engl J Med 2007; 356 : 1915-27.

42. Muñoz N, Kjaer SK, Sigurdsson K et al. Impact of human papillomavirus (HPV)-6/11/16/18 vaccine on all HPV-associated genital diseases in young women. J Natl Cancer Inst 2010; 102: 325-39.

43. Status for HPV-vaksinasjon. www. fhi.no (30.5.2011).

44. Cuzick J Castañón A Sasieni P. Predicted impact of vaccination against human papillomavirus 16/18 on cancer incidence and cervical abnormalities in women aged 20-29 in the UK. Br J Cancer 2010; 102: $933-9$.

Mottatt 26.1. 2011, første revisjon innsendt 14.4 2011, godkjent 26.5. 2011. Medisinsk redaktør Are Brean 